\title{
Energy and Water Conservation Measures for Hanford (2013)
}

\section{DJ Reid}

RS Butner

April 2013

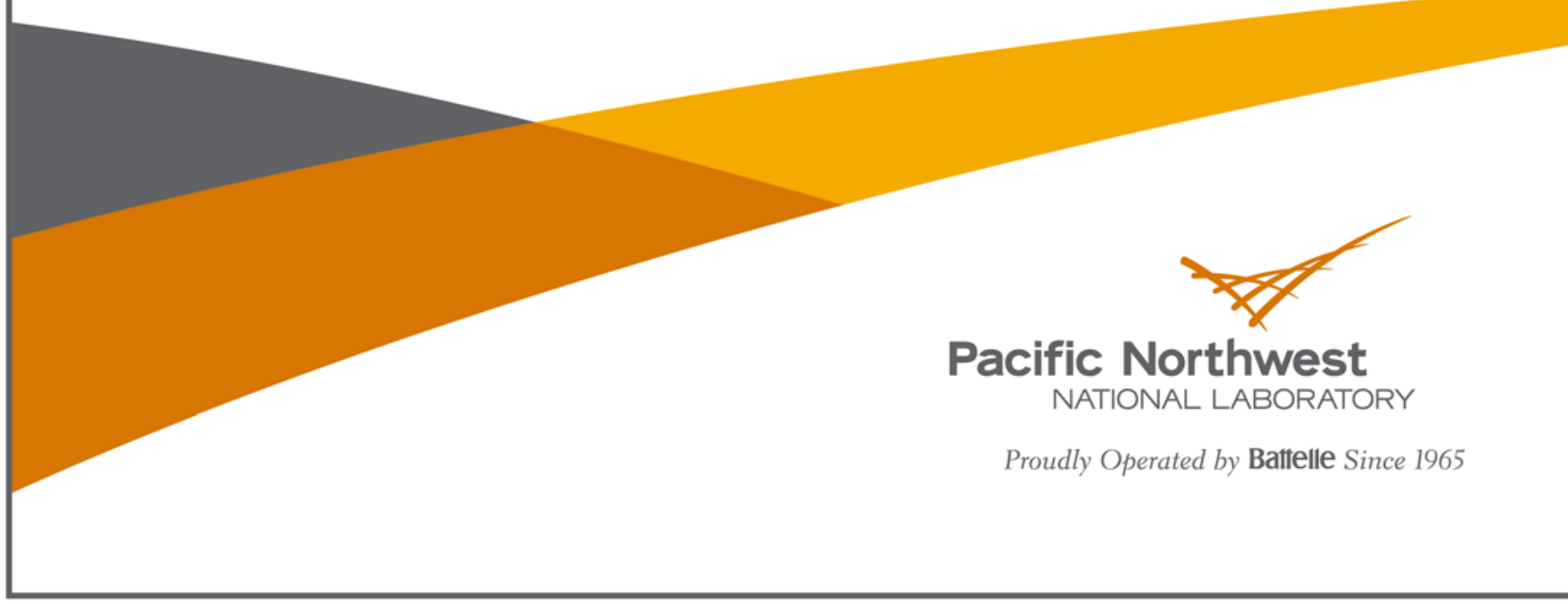




\title{
DISCLAIMER
}

This report was prepared as an account of work sponsored by an agency of the United States Government. Neither the United States Government nor any agency thereof, nor Battelle Memorial Institute, nor any of their employees, makes any warranty, express or implied, or assumes any legal liability or responsibility for the accuracy, completeness, or usefulness of any information, apparatus, product, or process disclosed, or represents that its use would not infringe privately owned rights. Reference herein to any specific commercial product, process, or service by trade name, trademark, manufacturer, or otherwise does not necessarily constitute or imply its endorsement, recommendation, or favoring by the United States Government or any agency thereof, or Battelle Memorial Institute. The views and opinions of authors expressed herein do not necessarily state or reflect those of the United States Government or any agency thereof.

\author{
PACIFIC NORTHWEST NATIONAL LABORATORY \\ operated by \\ BATTELLE \\ for the \\ UNITED STATES DEPARTMENT OF ENERGY \\ under Contract DE-AC05-76RL01830
}

Printed in the United States of America

Available to $D O E$ and DOE contractors from the

Office of Scientific and Technical Information,

P.O. Box 62, Oak Ridge, TN 37831-0062;

ph: (865) 576-8401

fax: $(865) 576-5728$

email: reports $a$ adonis.osti.gov

Available to the public from the National Technical Information Service

5301 Shawnee Rd., Alexandria, VA 22312

ph: (800) 553-NTIS (6847)

email: ordersantis.gov <http://www.ntis.gov/about/form.aspx>

Online ordering: http://www.ntis.gov 


\section{Energy and Water Conservation Measures for Hanford (2013)}

DJ Reid

RS Butner

April 2013

Prepared for

the U.S. Department of Energy

under Contract DE-AC05-76RL01830

Pacific Northwest National Laboratory

Richland, Washington 99352 



\section{Executive Summary}

Pacific Northwest National Laboratory (PNNL) performed an energy and water evaluation of selected buildings on the Hanford Site during the months of May and June 2012. The audit was performed under the direction of the U.S. Department of Energy, Sustainability Performance Office to identify key energy conservation measures (ECMs) and water conservation measures (WCMs). The evaluations consisted of on-site facility walk-throughs conducted by PNNL staff, interviews with building-operating personnel, and an examination of building designs and layouts. Information on 38 buildings was collected to develop a list of energy and water conservation measures. Table ES.1 is a summary of the ECMs, while table ES.2 is a summary of the WCMs.

Table ES.1. Summary of Hanford Energy Conservation Measures

\begin{tabular}{|c|c|c|c|c|}
\hline Measure Description & $\begin{array}{c}\text { Annual Electricity } \\
\text { Savings } \\
\text { (kWh) }\end{array}$ & $\begin{array}{c}\text { Total Annual Cost } \\
\text { Savings }\end{array}$ & $\begin{array}{l}\text { Measure } \\
\text { Cost }\end{array}$ & $\begin{array}{c}\text { Simple } \\
\text { Payback } \\
\text { Range } \\
\text { (years) }^{b}\end{array}$ \\
\hline Interior Lighting & 126,122 & $\$ 16,023$ & $\$ 139,593$ & $5.5-13.8$ \\
\hline Lighting Controls & 237,145 & $\$ 27,151$ & $\$ 60,958$ & $0.3-7.7$ \\
\hline $\mathrm{HVAC}^{\mathrm{a}}$ & 180,966 & $\$ 18,440$ & $\$ 198,668$ & $8-13.5$ \\
\hline Exterior Lighting & 23,913 & $\$ 1,571$ & $\$ 10,684$ & $5.3-12$ \\
\hline Weather Stripping & 94,151 & $\$ 7,310$ & $\$ 27,780$ & $3.4-4.2$ \\
\hline Programmable Thermostats & 64,525 & $\$ 5,684$ & $\$ 1,392$ & $0.1-0.5$ \\
\hline Outlet Strips & 29,520 & $\$ 2,246$ & $\$ 15,955$ & 7.1 \\
\hline Totals & 756,342 & $\$ 78,425$ & $\$ 455,030$ & ----- \\
\hline
\end{tabular}

(a) Heating, ventilating, and air conditioning

(b) Varies by specific building 
Table ES.2. Summary of Hanford Water Conservation Measures

\begin{tabular}{|c|c|c|}
\hline Description & Annual Savings (kGal) & $\begin{array}{l}\text { Measure and } \\
\text { Installation } \\
\text { Cost }\end{array}$ \\
\hline $\begin{array}{c}\text { Replace lavatory sink } \\
\text { aerators in restrooms }\left(0.5 \mathrm{gpm}^{\mathrm{a}}\right)\end{array}$ & 379.8 & $\$ 1,214$ \\
\hline $\begin{array}{l}\text { Replace urinals with pint } \\
\text { flush models }\left(1 / 8 \mathrm{gpf}^{\mathrm{b}}\right)\end{array}$ & 196.0 & $\$ 35,759$ \\
\hline $\begin{array}{l}\text { Replace water closets with } \\
\text { low flush models (1.28 gpf) } \\
\text { (existing } 1.6 \text { gpf water closets } \\
\text { excluded) }\end{array}$ & 361.0 & $\$ 35,597$ \\
\hline $\begin{array}{r}\text { Replace Shower heads with } \\
\text { low-flow, } 1.9 \text { gpm shower heads }\end{array}$ & 7.2 & $\$ 455$ \\
\hline $\begin{array}{c}\text { Replace high flush toilets } \\
\text { with conventional, } 1.6 \text { gpf toilets }\end{array}$ & 298.6 & $\$ 34,075$ \\
\hline $\begin{array}{l}\text { Replace kitchen sink aerator } \\
\text { with low-flow kitchen sink, } \\
1.8 \text { gpm aerator }\end{array}$ & 30.2 & $\$ 79$ \\
\hline Totals & $1,272.8$ & $\$ 107,179$ \\
\hline
\end{tabular}
(a) gpm = gallons per minute
(b) $\mathrm{gpf}=$ gallons per flush
(c) $\mathrm{kGal}=1,000$ gallons 


\title{
Acronyms and Abbreviations
}

\author{
$\mathrm{CMH} \quad$ ceramic metal halide \\ ECM energy conservation measure \\ FEDS Facility Energy Decision System \\ gpf gallons per flush \\ gpm gallons per minute \\ HVAC heating, ventilating, and air conditioning \\ kGal $\quad 1,000$ gallons \\ LED light-emitting diode \\ PNNL Pacific Northwest National Laboratory \\ WCM water conservation measure
}





\section{Contents}

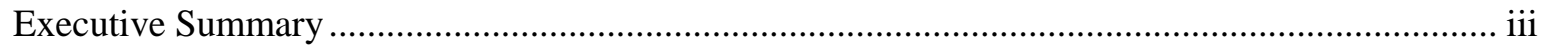

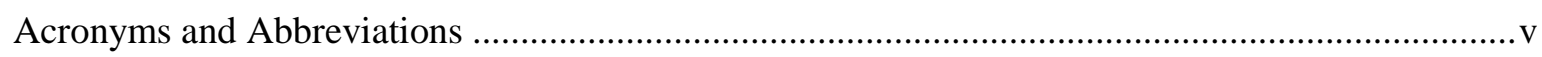

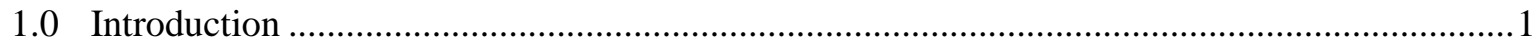

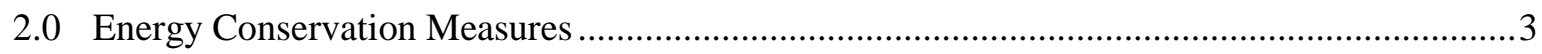

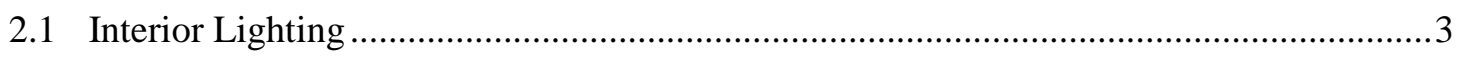

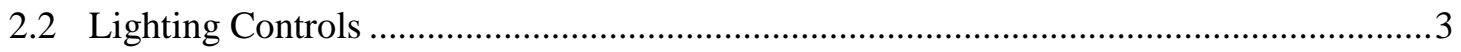

2.3 Heating, Ventilating and Air Conditioning (HVAC) ….................................................

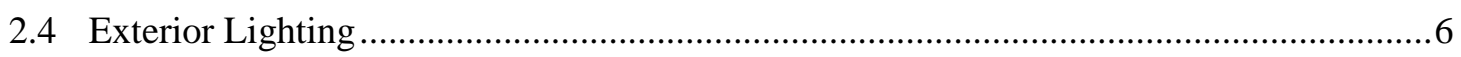

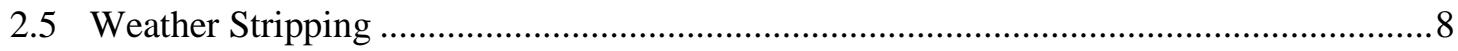

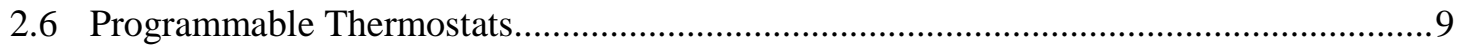

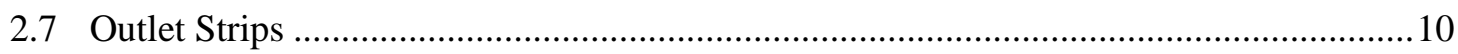

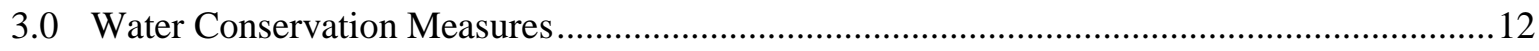

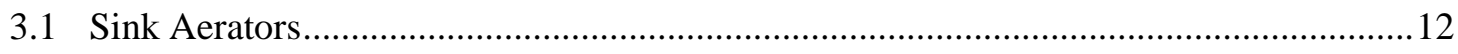

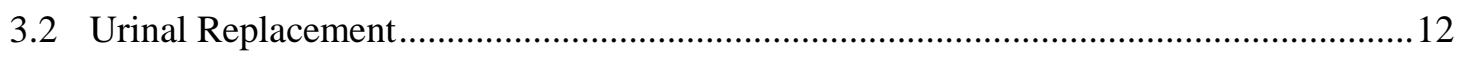

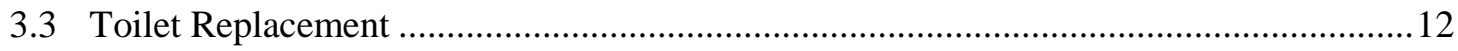

3.4 Shower Head Replacement ..................................................................................... 13

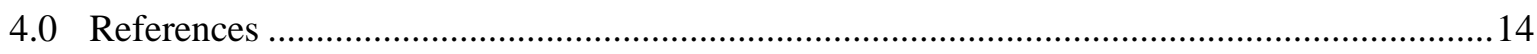




\section{Figures}

Figure 2.2. Multiple HVAC Units on a Mobile Office ................................................................5

Figure 2.3. Multiple Rooftop HVAC Units on Building 3790 ....................................................6

Figure 2.4. High Efficiency Lighting ....................................................................................

\section{Tables}

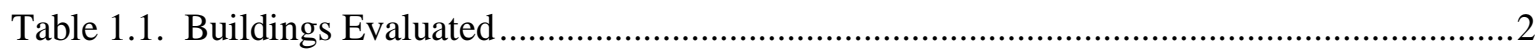

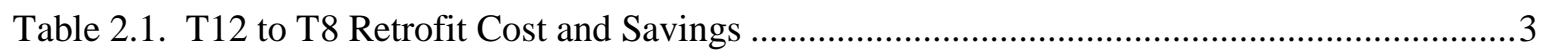

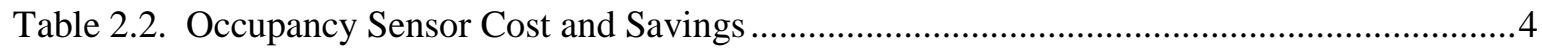

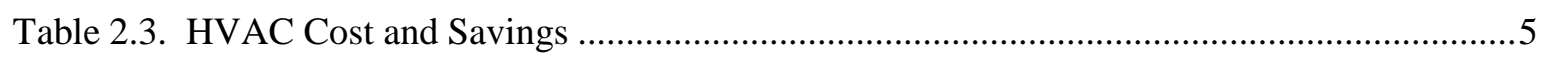

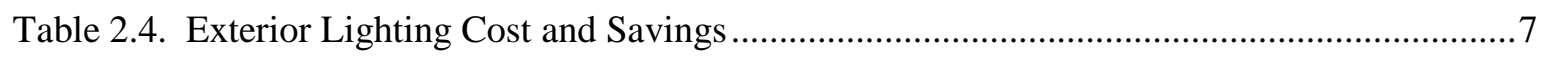

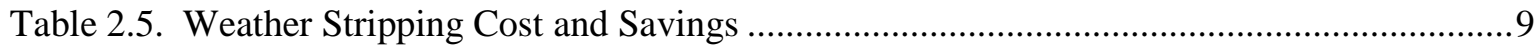

Table 2.6. Programmable Thermostat Cost and Savings ........................................................... 10

Table 2.7. Outlet Strip Cost and Savings ............................................................................. 11 


\subsection{Introduction}

Pacific Northwest National Laboratory (PNNL) performed an energy and water evaluation of 38 selected buildings on the Hanford Site during the months of May and June 2012. These evaluations were performed under the direction of the U.S. Department of Energy, Sustainability Performance Office to identify key energy conservation measures (ECMs) and water conservation measures (WCMs). This effort assisted the Department of Energy in meeting the EISA 432 requirements (EISA 2007). The evaluation team identified key ECM and WCM measures that could be implemented within the next year.

For all ECMs identified, the following information was provided: property ID, gross square feet of the building, description of each proposed ECM, electricity savings ( $\mathrm{kWh}$ ), total cost savings, measure cost, and simple payback (years). These calculations were based on the $\$ 0.076$ per kWh electricity rate that is charged by the utilities supplying electricity to the Hanford Site to make sure that the proposed ECMs will indeed be cost-effective at the site.

For all WCMs identified, the following information was provided: Hanford area, property ID, gross square feet, description of each proposed WCM, quantity, existing flow rate, annual savings (kGal), reduction (\%), and cost.

Mission Support Alliance LLC (MSA ${ }^{1}$ ), the on-site contractor at Hanford, asked PNNL to take a graded approach to assessing the Hanford buildings. For some buildings, no ECMs were identified: several of the audited buildings were scheduled for demolition in the next couple of years; several others were recently constructed and are Leadership in Energy and Environmental Design (LEED)-certified buildings. The remaining buildings were divided into two classifications. The first group of 16 buildings warranted running a full Facility Energy Decision System (FEDS) model (FEDS 2012), and this analysis was performed. Creating a full FEDS model for a building is time consuming, but it gives the ability to assess the full impact of a retrofit on the entire building system. For example, an internal lighting retrofit has an impact on the HVAC load because of the energy emitted by the lights. With the exception of HVAC measures, primarily low-cost and low disruption measures were considered. For this analysis, a "low disruption" measure is any work that would not require the building to be completely vacated, or to have normal activities suspended, during the ECM installation. For those 16 building plus an additional five buildings, spreadsheets were used to calculate ECMs. PNNL developed a number of Excel ${ }^{\circledR}$ spreadsheets that were used to assess simplified life-cycle cost analysis for low-cost/no-cost measures. The buildings that were evaluated are listed in Table ES.1. The first column identifies the buildings that were modeled with FEDS and the second column identifies the buildings for which spreadsheets were used.

\footnotetext{
${ }^{1}$ http://www.hanford.gov/page.cfm/MSA
} 
Table 1.1. Buildings Evaluated

\begin{tabular}{|c|c|c|}
\hline Building ID & Model with FEDS (X) & Assess with Spreadsheets (X) \\
\hline 664 & & \\
\hline 3212 & & \\
\hline $105 \mathrm{~B}$ & & \\
\hline $218 \mathrm{~A}$ & & \\
\hline $2268 \mathrm{E}$ & & \\
\hline 2269E & & \\
\hline $227 \mathrm{~S}$ & & \\
\hline $2610 \mathrm{E}$ & & \\
\hline 2611E & & \\
\hline $270 \mathrm{Z}$ & & \\
\hline 2713S & & \\
\hline 273W & & \\
\hline 274AW & & \\
\hline 2404WB & & \\
\hline 289T & & \\
\hline 289TA & & \\
\hline 6251 & & \\
\hline $273 E$ & & $\mathrm{X}$ \\
\hline $282 \mathrm{~W}$ & & $\mathrm{X}$ \\
\hline 283E & & $\mathrm{X}$ \\
\hline MO607 & & $\mathrm{X}$ \\
\hline 2403WA & & $\mathrm{X}$ \\
\hline 616 & $\mathrm{X}$ & $\mathrm{X}$ \\
\hline 3790 & $\mathrm{X}$ & $\mathrm{X}$ \\
\hline $251 \mathrm{~W}$ & $\mathrm{X}$ & $\mathrm{X}$ \\
\hline 2704S & $\mathrm{X}$ & $\mathrm{X}$ \\
\hline $662 \mathrm{~A}$ & $\mathrm{X}$ & $\mathrm{X}$ \\
\hline MO277 & $\mathrm{X}$ & $\mathrm{X}$ \\
\hline MO278 & $\mathrm{X}$ & $\mathrm{X}$ \\
\hline MO279 & $\mathrm{X}$ & $\mathrm{X}$ \\
\hline MO281 & $\mathrm{X}$ & $\mathrm{X}$ \\
\hline MO285 & $\mathrm{X}$ & $\mathrm{X}$ \\
\hline MO286 & $\mathrm{X}$ & $\mathrm{X}$ \\
\hline MO287 & $\mathrm{X}$ & $\mathrm{X}$ \\
\hline MO294 & $\mathrm{X}$ & $\mathrm{X}$ \\
\hline MO412 & $\mathrm{X}$ & $\mathrm{X}$ \\
\hline MO720 & $\mathrm{X}$ & $\mathrm{X}$ \\
\hline 2101HV & $\mathrm{X}$ & $\mathrm{X}$ \\
\hline
\end{tabular}




\subsection{Energy Conservation Measures}

\subsection{Interior Lighting}

The majority of the lighting surveyed was standard T12 fluorescent lamps with magnetic ballasts. Electronic high frequency ballasts are more efficient than magnetic ballasts in converting input power to the proper lamp power, which reduces losses, saving energy and costs. All future projects should include upgrading the existing T12 fixtures and lamps with high efficiency electronic ballasts and lamps.

If a lighting replacement project is funded, consider implementing the project as a group relamping project. This approach typically reduces the labor costs and the payback.

The FEDS software (FEDS 2012) was used to calculate the data in Table 2.1.

Table 2.1. T12 to T8 Retrofit Cost and Savings

\begin{tabular}{|l|c|c|c|c|c|c|}
\hline & $\begin{array}{c}\text { Existing T12 } \\
\text { Fluorescent } \\
\text { Fixture Type } \\
\text { (lamp count) }\end{array}$ & $\begin{array}{c}\text { Number } \\
\text { of } \\
\text { Fixtures }\end{array}$ & $\begin{array}{c}\text { Annual } \\
\text { Electricity } \\
\text { Savings (kWh) }\end{array}$ & $\begin{array}{c}\text { Total Annual } \\
\text { Cost Savings }\end{array}$ & $\begin{array}{c}\text { Measure } \\
\text { Cost }\end{array}$ & $\begin{array}{c}\text { Simple } \\
\text { Payback } \\
\text { (years) }\end{array}$ \\
\hline 3790 & $2 \times 4$ & 121 & 41,942 & $\$ 4,784$ & $\$ 34,922$ & 7.3 \\
\hline 3790 & $2 \times 2$ & 24 & 2,640 & $\$ 510$ & $\$ 4,951$ & 9.7 \\
\hline 3790 & $1 \times 4$ & 7 & 1,467 & $\$ 190$ & $\$ 1,047$ & 5.5 \\
\hline $662 \mathrm{~A}$ & $2 \times 4$ & 16 & 3,520 & $\$ 366$ & $\$ 4,350$ & 11.9 \\
\hline $2101 \mathrm{HV}$ & $1 \times 4$ & 9 & 1,760 & $\$ 245$ & $\$ 1,346$ & 5.5 \\
\hline $2704 \mathrm{~S}$ & $1 \times 4$ & 35 & 4,400 & $\$ 575$ & $\$ 5,236$ & 9.1 \\
\hline MO281 & $2 \times 4$ & 112 & 18,478 & $\$ 2,440$ & $\$ 21,229$ & 8.7 \\
\hline MO278 & $2 \times 4$ & 102 & 10,266 & $\$ 1,334$ & $\$ 17,873$ & 13.4 \\
\hline MO279 & $2 \times 4(2$ lamp) & 102 & 18,185 & $\$ 2,448$ & $\$ 17,873$ & 7.3 \\
\hline MO279 & $2 \times 4(3 \mathrm{lamp})$ & 50 & 4,986 & $\$ 691$ & $\$ 9,537$ & 13.8 \\
\hline MO720 & $2 \times 4$ & 112 & 18,478 & $\$ 2,440$ & $\$ 21,229$ & 8.7 \\
\hline Totals & & & 126,122 & $\$ 16,023$ & $\$ 139,593$ & \\
\hline
\end{tabular}

\subsection{Lighting Controls}

During the evaluations, many outside lights (that appeared to have sensors) were on during the daytime. Many common-area lights (i.e., restrooms and conference rooms) were on in areas that were unoccupied. Even in private offices that were unoccupied or only partially occupied all the lights were on in the space. Most of the indoor areas had no automatic control of the lights.

In addition, some of the common areas such as hallways and offices were measured and appeared to be over-lit compared to what is typically expected for that type of space. Many of the offices had manual switches operating two separate sets of light circuits. With both sets of light circuits activated, the area was well over-lit. 
Occupancy sensors range in price from $\$ 30$ to $\$ 130$ depending on the types. Payback is usually 0.5 to 5 years depending on the level of occupancy and energy unit costs (USI 2004). Numerous studies have been associated with savings in various spaces.

PNNL's Lighting Occupancy Sensor Project Development Template (Duan et al. 2012.) was used to calculate the savings in Table 2.2.

Table 2.2. Occupancy Sensor Cost and Savings

\begin{tabular}{|l|c|c|c|c|}
\hline $\begin{array}{c}\text { Property } \\
\text { ID }\end{array}$ & $\begin{array}{c}\text { Annual } \\
\text { Electricity } \\
\text { Savings (kWh) }\end{array}$ & $\begin{array}{c}\text { Total } \\
\text { Annual Cost } \\
\text { Savings }\end{array}$ & $\begin{array}{c}\text { Measure } \\
\text { Cost }\end{array}$ & $\begin{array}{c}\text { Simple } \\
\text { Payback } \\
\text { (years) }\end{array}$ \\
\hline 282W & 769 & $\$ 103$ & $\$ 564$ & 5.5 \\
\hline $283 \mathrm{E}$ & 2,568 & $\$ 847$ & $\$ 847$ & 1.0 \\
\hline $2403 W \mathrm{~A}$ & 5,871 & $\$ 787$ & $\$ 3,951$ & 5.0 \\
\hline 616 & 5,242 & $\$ 703$ & $\$ 1,129$ & 1.6 \\
\hline 3790 & 61,529 & $\$ 6,668$ & $\$ 1,976$ & 0.3 \\
\hline $251 \mathrm{~W}$ & 6,486 & $\$ 570$ & $\$ 564$ & 1.0 \\
\hline $2704 \mathrm{~S}$ & 10,385 & $\$ 1,025$ & $\$ 847$ & 0.8 \\
\hline $662 \mathrm{~A}$ & 4,810 & $\$ 1,058$ & $\$ 847$ & 0.8 \\
\hline MO277 & 13,418 & $\$ 1,188$ & $\$ 6,773$ & 5.7 \\
\hline MO278 & 10,483 & $\$ 1,411$ & $\$ 5,080$ & 3.6 \\
\hline MO279 & 13,104 & $\$ 1,613$ & $\$ 6,773$ & 4.2 \\
\hline MO281 & 33,546 & $\$ 3,763$ & $\$ 6,773$ & 1.8 \\
\hline MO286 & 12,580 & $\$ 1,575$ & $\$ 6,773$ & 4.3 \\
\hline MO287 & 14,089 & $\$ 1,188$ & $\$ 6,773$ & 5.7 \\
\hline MO412 & 5,032 & $\$ 550$ & $\$ 4,233$ & 7.7 \\
\hline MO720 & 33,546 & $\$ 3,763$ & $\$ 6,773$ & 1.8 \\
\hline $2101 H V$ & 3,687 & $\$ 339$ & $\$ 282$ & 0.8 \\
\hline Totals & 237,145 & $\$ 27,151$ & $\$ 60,958$ & \\
\hline
\end{tabular}

Add occupancy sensors in as many office or laboratory areas where shifts are not 24/7, and add lighting occupancy sensors to all common areas, such as conference rooms, lunchrooms and restrooms.

Sensors should be located such that they are capable of detecting staff working in the building space. Misplaced sensors can result in occupant discomfort if occupants are working in an area that is not within range of the sensor. Multiple sensors may be necessary to provide proper performance.

Consider the presence of any large pieces of equipment, vehicles, or other objects that may obscure working areas from the sensor's line of sight. 


\subsection{Heating, Ventilating and Air Conditioning (HVAC)}

The FEDS software (FEDS 2012) was used to calculate the costs and savings shown in Table 2.3. HVAC measures were considered for all FEDS-run buildings, but only four buildings showed cost-effective measures.

Table 2.3. HVAC Cost and Savings

\begin{tabular}{|l|c|c|c|c|}
\hline Property ID & $\begin{array}{c}\text { Annual } \\
\text { Electricity } \\
\text { Savings (kWh) }\end{array}$ & $\begin{array}{c}\text { Total Annual } \\
\text { Cost Savings }\end{array}$ & $\begin{array}{c}\text { Simple } \\
\text { Measure } \\
\text { Cost }\end{array}$ & $\begin{array}{c}\text { Sayback } \\
\text { (years) }\end{array}$ \\
\hline MO277 & 51,328 & $\$ 5,212$ & $\$ 41,697$ & 8 \\
\hline MO287 & 17,011 & $\$ 2,673$ & $\$ 36,081$ & 13.5 \\
\hline 3790 & 95,909 & $\$ 7,901$ & $\$ 85,328$ & 10.8 \\
\hline MO294 & 16,718 & $\$ 2,654$ & $\$ 35,562$ & 13.4 \\
\hline Totals & 180,966 & $\$ 18,440$ & $\$ 198,668$ & \\
\hline
\end{tabular}

Figure 2.1 shows multiple older HVAC units on the side of a mobile office. Figure 2.2 shows multiple 1980s-vintage rooftop HVAC units on building 3790. The FEDS model suggests replacing the 12 existing units with four new very high efficiency air-source heat pumps.

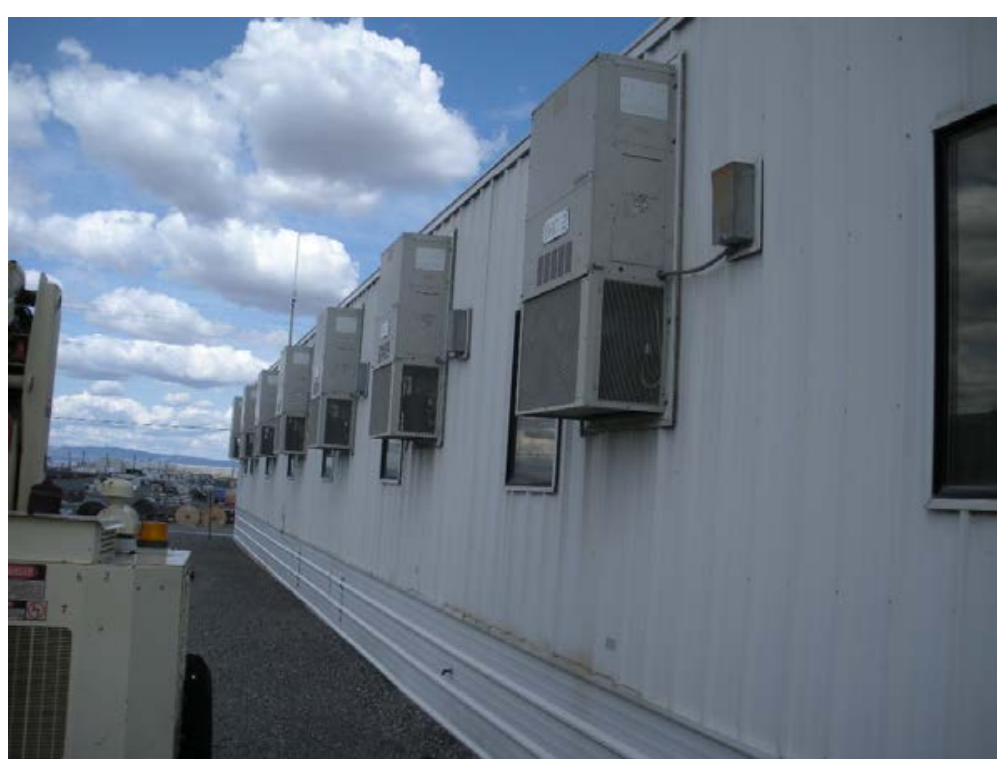

Figure 2.1. Multiple HVAC Units on a Mobile Office 


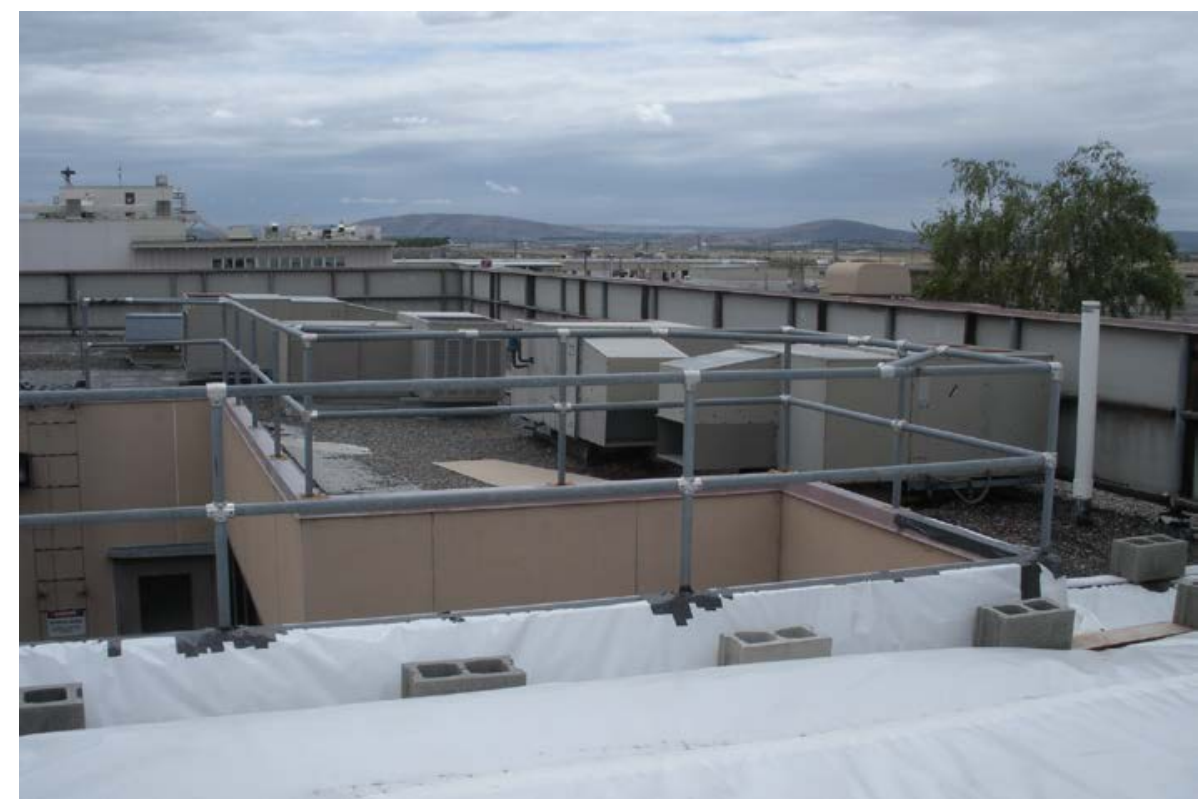

Figure 2.2. Multiple Rooftop HVAC Units on Building 3790

\subsection{Exterior Lighting}

All of the buildings audited contained some form of exterior lighting to provide lighting for safety and security to the buildings and their surrounding areas. The evaluations revealed that these lights were predominantly high-pressure sodium bulbs of approximately 50 to 150 watts, though some buildings utilized higher-wattage metal halide bulbs. Replacing high-pressure sodium lights with a more energy efficient alternative, such as ceramic metal halide $(\mathrm{CMH})$ bulbs can be a relatively easy and quick way to reduce building energy consumption.

There are several alternative replacements available to conserve energy. CMH bulbs range in price from $\$ 30$ to $\$ 70$ depending on the types. Paybacks on these measures are usually between 0.5 to 5 years; however, because of the low electricity rates found in the Pacific Northwest (\$0.076/kWh at Hanford), payback periods on these measures are much longer, ranging from 5 years to over 15 years. Lightemitting diode (LED) lamps were another option identified during the analysis, though these were not cost-effective in the majority of cases. Payback was usually longer than 15 years depending on the level of use and energy unit costs.

High efficiency exterior lighting such as shown in Figure 2.3 can save energy by using less energy to illuminate building entrances and their surrounding areas. 


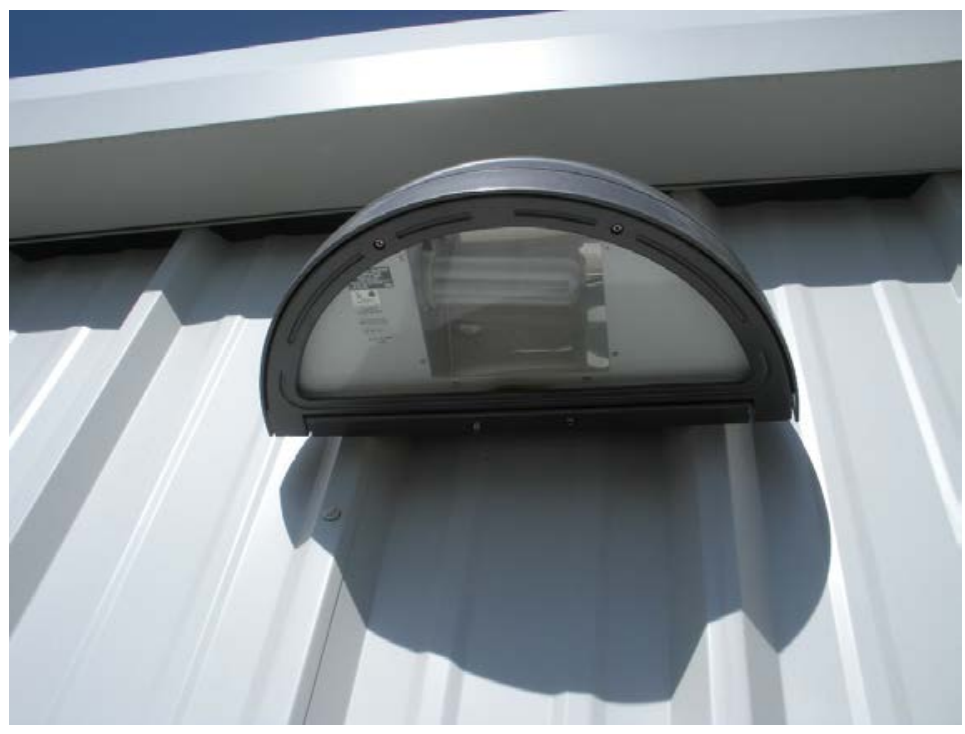

Figure 2.3. High Efficiency Lighting

To determine the potential savings, an analysis was performed for the replacement of all exterior lights associated with each building (Reid and Athalye 2012). In general, the mobile offices had only a few 50 to 150 watt high-pressure sodium bulbs for exterior lighting and represented the smallest savings opportunity; most of them had simple paybacks exceeding 13 or 14 years. Warehouses and other permanent structures examined, which had more powerful exterior lights, were more likely to have costeffective conservation measures. Table 2.4 lists the buildings where exterior light replacement is cost-effective. In some cases $\mathrm{CMH}$ fixtures are more cost-effective. In other instances induction (IND) lights are the preferred choice. In still other instances LED fixture replacements make sense.

Table 2.4. Exterior Lighting Cost and Savings

\begin{tabular}{|l|c|c|c|c|c|}
\hline & $\begin{array}{c}\text { Annual } \\
\text { Electricity } \\
\text { Property ID } \\
\text { Savings (kWh) }\end{array}$ & $\begin{array}{c}\text { Total } \\
\text { Annual Cost } \\
\text { Savings }\end{array}$ & $\begin{array}{c}\text { Measure } \\
\text { Cost }\end{array}$ & $\begin{array}{c}\text { Simple } \\
\text { Payback } \\
\text { (years) }\end{array}$ & $\begin{array}{c}\text { Lighting } \\
\text { Technology }\end{array}$ \\
\hline $273 \mathrm{E}$ & 4,095 & $\$ 446$ & $\$ 3,480$ & 7.8 & IND \\
\hline $283 \mathrm{E}$ & 2,889 & $\$ 145$ & $\$ 766$ & 5.3 & $\mathrm{CMH}$ \\
\hline $2403 \mathrm{WA}$ & 8,667 & $\$ 433$ & $\$ 2,297$ & 5.3 & $\mathrm{CMH}$ \\
\hline $282 \mathrm{~W}$ & 1,040 & $\$ 186$ & $\$ 2,227$ & 12 & LED \\
\hline $2101 \mathrm{HV}$ & 7,222 & $\$ 361$ & $\$ 1,914$ & 5.3 & $\mathrm{CMH}$ \\
\hline Totals & 23,913 & $\$ 1,571$ & $\$ 10,684$ & & \\
\hline
\end{tabular}

In addition to lighting upgrades, turning outside lights off during the day can save significant amounts of energy. Those light fixtures that have photo sensors should be evaluated and moved to a better location to enable them to shut off when not needed, or if the location is adequate, check to make sure that the photo eye is not dirty, creating a false reading and turning on the light during the day.

Turn outside lights off during the day. Those light fixtures that have photo sensors should be evaluated and, if necessary, moved to a better location to enable them to shut off when not needed. If the photo sensor location is adequate, check to make sure that the photo eye is not dirty, thus creating a false 
reading and turning on the light during the day. Error! Reference source not found. shows an external light that was left on during the day.

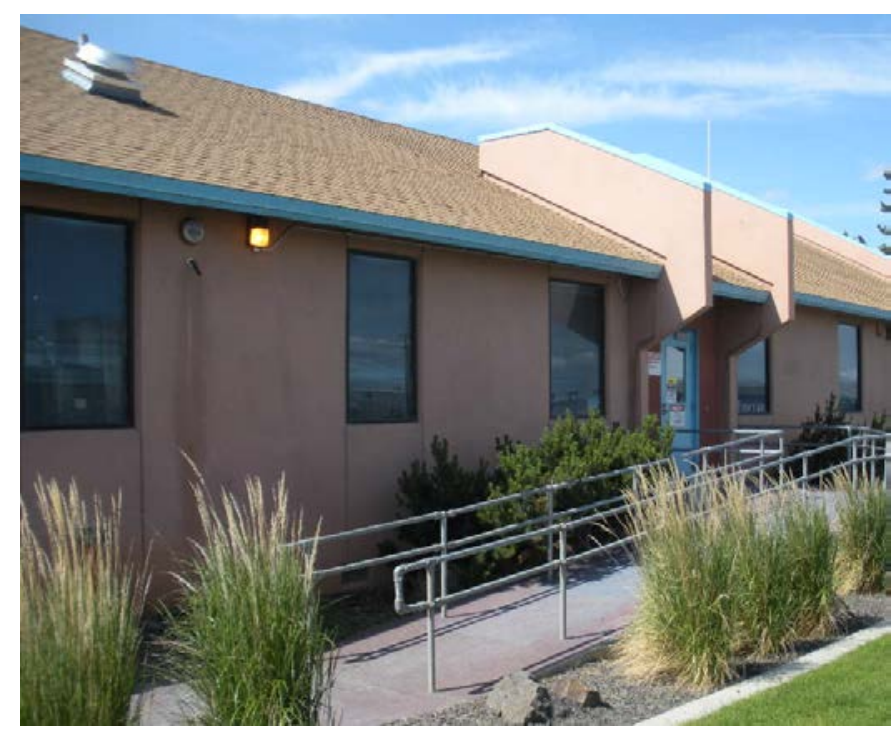

Figure 2.5. Exterior Lights on During the Day

\subsection{Weather Stripping}

Weather stripping acts as a key component of a building's air barrier by sealing the openings in the building's thermal barrier around the doors and windows. Over time these materials can wear down from use or exposure to the weather to the point that they begin to fail, allowing outside air to leak into the building interior. Replacing worn or degraded weather stripping can improve the tightness of a building's air envelope, reducing the energy needed to heat or cool it.

Replacing damaged weather stripping is a straightforward process that can be done with relatively minor disruption to the facility for a low cost. Weather stripping is a low-cost item requiring minimal labor to install and minimal upkeep. Paybacks on the measures identified for the Hanford Site were typically under 4 years.

To determine the potential savings, an analysis was performed for the replacement of all worn weather stripping on each building (Reid 2012b). Table 2.5 presents the results of the analysis. 
Table 2.5. Weather Stripping Cost and Savings

\begin{tabular}{|l|c|c|c|c|}
\hline $\begin{array}{c}\text { Property } \\
\text { ID }\end{array}$ & $\begin{array}{c}\text { Annual } \\
\text { Electricity } \\
\text { Savings (kWh) } \\
616\end{array}$ & $\begin{array}{c}\text { Total Annual } \\
\text { Cost Savings } \\
\$ 316\end{array}$ & $\begin{array}{c}\text { Measure } \\
\text { Cost } \\
\$ 1,328\end{array}$ & $\begin{array}{c}\text { Simple } \\
\text { Payback } \\
\text { (years) } \\
4.2\end{array}$ \\
\hline 3790 & 13,785 & $\$ 1,028$ & $\$ 4,008$ & 3.9 \\
\hline 251W & 2,933 & $\$ 230$ & $\$ 783$ & 3.4 \\
\hline 2704S & 7,626 & $\$ 586$ & $\$ 2,227$ & 3.8 \\
\hline $662 \mathrm{~A}$ & 2,640 & $\$ 209$ & $\$ 731$ & 3.5 \\
\hline MO277 & 8,212 & $\$ 618$ & $\$ 2,349$ & 3.8 \\
\hline MO278 & 5,573 & $\$ 410$ & $\$ 1,557$ & 3.8 \\
\hline MO279 & 5,573 & $\$ 410$ & $\$ 1,557$ & 3.8 \\
\hline MO281 & 5,573 & $\$ 655$ & $\$ 2,488$ & 3.8 \\
\hline MO285 & 5,573 & $\$ 415$ & $\$ 1,577$ & 3.8 \\
\hline MO286 & 5,573 & $\$ 415$ & $\$ 1,577$ & 3.8 \\
\hline MO287 & 5,573 & $\$ 415$ & $\$ 1,577$ & 3.8 \\
\hline MO294 & 8,506 & $\$ 637$ & $\$ 2,419$ & 3.8 \\
\hline MO412 & 4,693 & $\$ 348$ & $\$ 1,253$ & 3.6 \\
\hline MO720 & 8,212 & $\$ 618$ & $\$ 2,349$ & 3.8 \\
\hline Totals & 94,151 & $\$ 7,310$ & $\$ 27,780$ & \\
\hline
\end{tabular}

\subsection{Programmable Thermostats}

Buildings that are left with their thermostats set to a constant point waste energy by requiring the conditioning equipment to maintain that temperature in the building at all times, regardless of whether it is occupied. Programmable thermostats allow building operators to automatically adjust the building's temperature during different times of the day. By allowing the building's temperature to rise or fall a few additional degrees during unoccupied hours, returning to the desired temperature an hour or two before building occupants begin arriving, considerable energy savings can be achieved. Additionally, thermostats can be set back (winter) or up (summer) by a few degrees and save considerable amounts of energy without significantly affecting occupant comfort.

Non-programmable thermostats can be replaced at a relatively minor cost, typically around \$200 per unit, allowing building operators to set conditioning levels based on the hours when a building is occupied. All of the mobile offices visited during site audits already had programmable thermostats, but a number of other facilities examined did not. Analysis conducted to determine the potential savings indicate that the addition of programmable thermostats would have a very quick payback period — under a year in all of the buildings examined (Reid 2012b). Table 2.6 presents the results of the analysis. 
Table 2.6. Programmable Thermostat Cost and Savings

\begin{tabular}{|l|c|c|c|c|}
\hline $\begin{array}{c}\text { Property } \\
\text { ID }\end{array}$ & $\begin{array}{c}\text { Annual } \\
\text { Electricity } \\
\text { Savings (kWh) }\end{array}$ & $\begin{array}{c}\text { Total Annual } \\
\text { Cost Savings }\end{array}$ & $\begin{array}{c}\text { Measure } \\
\text { Cost }\end{array}$ & $\begin{array}{c}\text { Simple } \\
\text { Payback } \\
\text { (years) }\end{array}$ \\
\hline $273 \mathrm{E}$ & 7,039 & $\$ 580$ & $\$ 232$ & 0.4 \\
\hline 616 & 12,905 & $\$ 1,160$ & $\$ 232$ & 0.2 \\
\hline 3790 & 22,877 & $\$ 2,320$ & $\$ 232$ & 0.1 \\
\hline $251 \mathrm{~W}$ & 7,626 & $\$ 580$ & $\$ 232$ & 0.4 \\
\hline $2704 \mathrm{~S}$ & 8,212 & $\$ 580$ & $\$ 232$ & 0.4 \\
\hline $662 \mathrm{~A}$ & 5,866 & $\$ 464$ & $\$ 232$ & 0.5 \\
\hline Totals & 64,525 & $\$ 5,684$ & $\$ 1,392$ & \\
\hline
\end{tabular}

Installing programmable thermostats in conditioned facilities where they are not currently present is recommended. Verify that facilities already equipped with programmable thermostats are making use of them by raising or lowering the temperature setting as appropriate during unoccupied hours by consulting with the building operators. Another recommendation is to set the temperature higher during summer and lower during winter by 4 degrees or less. These changes can save considerable energy without significantly altering occupant comfort.

Figure 2. shows a simple programmable thermostat.

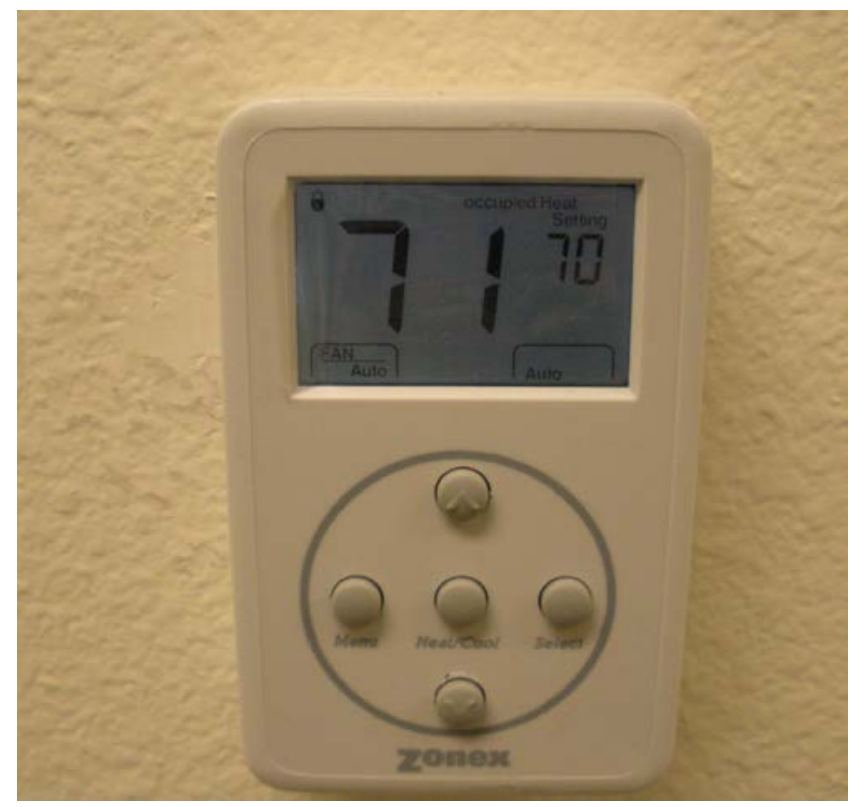

Figure 2.6. Programmable Thermostat

\subsection{Outlet Strips}

Load- or occupancy-sensitive outlet strips can conserve energy by detecting when the devices plugged into it enter into low-power mode (such as a desktop computer) and deactivating the other devices connected to the power strip that may be siphoning energy while not in use (such as electric pencil sharpeners). These outlet strips can save considerable electricity relative to their installation costs. It is 
recommended that load-sensing outlet strips be installed in all office buildings. This requires that the outlet strips are properly installed by the responsible parties such that computers are not accidentally turned off when they enter low-power mode.

There are several alternative outlet strip replacements available to conserve energy. "Smart" strips range in price from $\$ 40$ for load-sensing strips to $\$ 80$ for occupancy-sensing strips ${ }^{1}$. Installation costs are based almost exclusively upon the number of work stations in the building to be equipped with the outlet strips. Payback on these measures can be under a year, particularly in buildings with a large plug load that is typically left on at all times, such as an office. However, buildings with low plug loads or buildings that are only occasionally occupied may have simple payback periods in excess of 9 years. Table 2.7 presents the results of the analysis.

Table 2.7. Outlet Strip Cost and Savings

\begin{tabular}{|l|c|c|c|c|}
\hline $\begin{array}{c}\text { Property } \\
\text { ID }\end{array}$ & $\begin{array}{c}\text { Annual } \\
\text { Electricity } \\
\text { Savings (kWh) }\end{array}$ & $\begin{array}{c}\text { Total } \\
\text { Annual } \\
\text { Cost } \\
\text { Savings }\end{array}$ & $\begin{array}{c}\text { Measure } \\
\text { Cost }\end{array}$ & $\begin{array}{c}\text { Simple } \\
\text { Payback } \\
\text { (years) }\end{array}$ \\
\hline $273 \mathrm{E}$ & 600 & $\$ 46$ & $\$ 324$ & 7.1 \\
\hline $283 \mathrm{E}$ & 600 & $\$ 46$ & $\$ 324$ & 7.1 \\
\hline 616 & 600 & $\$ 46$ & $\$ 324$ & 7.1 \\
\hline 3790 & 2,760 & $\$ 210$ & $\$ 1,492$ & 7.1 \\
\hline $251 \mathrm{~W}$ & 2,760 & $\$ 210$ & $\$ 1,492$ & 7.1 \\
\hline $662 \mathrm{~A}$ & 1,200 & $\$ 91$ & $\$ 649$ & 7.1 \\
\hline MO277 & 4,800 & $\$ 365$ & $\$ 2,594$ & 7.1 \\
\hline MO278 & 4,800 & $\$ 365$ & $\$ 2,594$ & 7.1 \\
\hline MO279 & 240 & $\$ 18$ & $\$ 130$ & 7.1 \\
\hline MO281 & 3,600 & $\$ 274$ & $\$ 1,946$ & 7.1 \\
\hline MO286 & 1,560 & $\$ 119$ & $\$ 843$ & 7.1 \\
\hline MO287 & 1,440 & $\$ 109$ & $\$ 778$ & 7.1 \\
\hline MO412 & 720 & $\$ 55$ & $\$ 389$ & 7.1 \\
\hline MO720 & 3,600 & $\$ 274$ & $\$ 1,946$ & 7.1 \\
\hline $2101 H V$ & 240 & $\$ 18$ & $\$ 130$ & 7.1 \\
\hline Totals & 29,520 & $\$ 2,246$ & $\$ 15,955$ & \\
\hline
\end{tabular}

${ }^{1}$ Chvala, WD. 2012. Smart Power Strip Replacement Project Development Template. DRAFT. Pacific Northwest National Laboratory, Richland, Washington. 


\subsection{Water Conservation Measures}

Twenty-six buildings showed potential for WCMs. The summaries of PNNL's recommendations are detailed in the following sections.

\subsection{Sink Aerators}

The majority of buildings examined during the site evaluations contained faucets located in both the restrooms and staff kitchens. The evaluations revealed that these aerators on these faucets were predominantly operating at as little as 1 gallon per minute, with some being as high as 10 gallons per minute. Replace bathroom aerators with those rated at 0.5 gallons per minute, and kitchen sink aerators with 1.8 gallons per minute. These new aerators can typically be installed onto the existing sink faucet, making the equipment that is currently in place more efficient.

Aerators are widely available for under \$5 for bathroom sinks, and under \$20 for kitchen sinks. Installation typically requires minimal amounts of labor and disruption to the facilities. Together, the bathroom sink aerator replacements identified could save approximately 379,900 gal per year with a total project cost of approximately $\$ 1,200$. Kitchen sink aerator replacements identified could save approximately 30,000 gallons a year, costing $\$ 79$ in total. Replacing both kitchen and bathroom aerators could save a combined 410,000 gallons per year for a total cost of $\$ 1,293$. This is approximately 312.8 gallons of water saved per year per dollar invested in water conservation measures.

\subsection{Urinal Replacement}

With the exclusion of one or two storage facilities, all of the buildings examined during the site evaluations contained urinals. The evaluations revealed that these urinals typically consumed approximately 1 to 2 gallons per flush (gpf), though some had been recently replaced with 1-pint flush models; these were in the minority. Replacing urinals with those rated at 0.125 gallon ( 1 pint) per flush represents an opportunity for water conservation.

Including the price of labor to install the new urinals, replacement is estimated to cost approximately $\$ 832$ per urinal. Together, the urinal replacements identified by the site audits could save approximately 196,060 gallons per year with a total project cost of approximately $\$ 35,759$. These measures result in approximately 5.48 gallons saved per year per dollar invested into water conservation.

\subsection{Toilet Replacement}

The majority of buildings examined during the site evaluations contained toilets located in on-site restrooms. Fixtures in both men's and women's restrooms were characterized during the on-site visits. The evaluations revealed that while many toilets were more-efficient 1.6 gpf models, a number of the toilets were 3 gpf models, with some using as much as 4 gpf. Two options for water conservation were identified. In the first option, toilets consuming over $1.6 \mathrm{gpf}$ would be replaced with models that consume only 1.6 gallons per flush. Alternatively, high-consumption toilets could be replaced with even more efficient $1.28 \mathrm{gpf}$ models (while leaving those rated at $1.6 \mathrm{gpf}$ in place). 
Both models are available for approximately \$516 for 1.6 gpf toilets or 1.28 gpf toilets. Installation typically requires minimal amounts of labor and disruption to the facilities. Replacing the toilets identified in this report with 1.6 gpf models could save approximately 254,000 gallons per year for a total cost of $\$ 35,597$. Alternatively, replacing the toilets identified with $1.28 \mathrm{gpf}$ models could save 361,000 gallons per year at a total project cost of $\$ 35,597$. These measures, replacing toilets with 1.6 or 1.28 gpf models, would save approximately 8.76 and 10.14 gallons of water saved per year per dollar invested, respectively.

\subsection{Shower Head Replacement}

The majority of buildings examined during the site evaluation did not have showering facilities. In total, only three buildings were identified that would benefit from the replacement of the existing shower heads with low-flow 1.9 gpm shower heads. Similar to sink aerators, low-flow shower heads are a low-cost, minimally disruptive conservation measure, with replacement shower heads typically costing only $\$ 13$ each. Together, these replacements would cost a total of $\$ 455$, and save an estimated 7,200 gallons of water per year. This project would save approximately 15.8 gallons of water per year per dollar invested.

The installation costs for the aerator and shower head WCMs are estimates based on an average installation cost using a non-plumber at a single building with numerous available installation opportunities. The cost information was based on data provided by a firm that routinely installs WCMs at Federal sites. The costs do not consider limited installation opportunities, at dispersed locations, on a single site. 


\subsection{References}

Duan X, RA Athalye, and EM Wendel. 2012. Lighting Occupancy Sensor Project Development

Template. PNNL-SA-92460 Pacific Northwest National Laboratory, Richland, WA.

EISA 2007. Energy Independence and Security Act of 2007. 42 USC 17001. Public Law No. 110-140.

E Source. 2011. Business Energy Advisor: Smart Power Strips. E Source Companies LLC, Boulder, Colorado. Available at

http://www.esource.com/escrc/0013000000DP22YAAT/BEA1/PA/PA OfficeEquipment/PA-03

FEDS. 2012. Facility Energy Decision System. Pacific Northwest National Laboratory, Richland, Washington. Available at http://www.pnl.gov/feds/

Reid DJ. 2012a. Programmable Thermostat Project Development Template. PNNL-SA-92168, Pacific Northwest National Laboratory, Richland, Washington.

Reid DJ. 2012b. Weather Stripping Replacement Project Development Template. PNNL-SA-91859, Pacific Northwest National Laboratory, Richland, Washington.

Reid DJ and RA Athalye. 2012. Exterior High Intensity Discharge Lighting Replacement Project Development Template. PNNL-SA-92459 Pacific Northwest National Laboratory, Richland, Washington.

USI - Utility Savings Initiative. 2004. Occupancy Sensors Utility Savings Initiative (USI) - Fact Sheet. Available at http://www.p2pays.org/ref/32/31316.pdf 


\section{Distribution}

No. of

Copies

4 Local Distribution

Pacific Northwest National Laboratory

Doug Reid

(PDF)

Ryan Butner

(PDF)

Doug Dixon

(PDF)

Bill Sandusky

(PDF)

Distr.1 




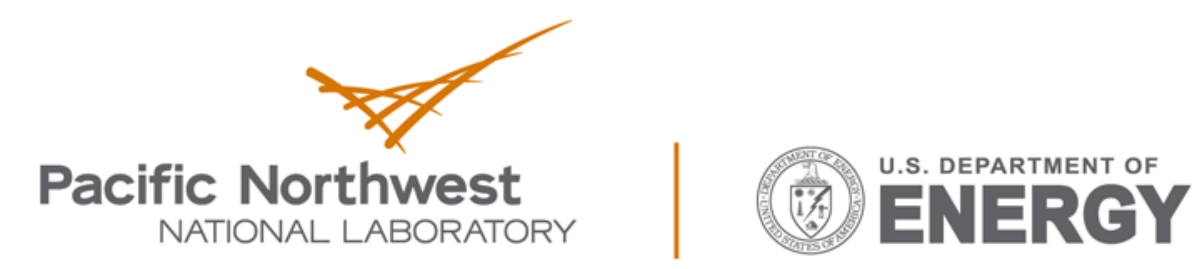

Proudly Operated by Battelle Since 1965

902 Battelle Boulevard

P.O. Box 999

Richland, WA 99352

1-888-375-PNNL (7665)

www.pnnl.gov 